\title{
Macedonia: Timely Prevention Works
}

\begin{abstract}
Three drivers led to war in Bosnia: breakup of Yugoslavia, Milošević's political ambitions and military capabilities, and ethnic nationalism. The first of these affected Macedonia. The other two were attenuated. Macedonia has mostly avoided war and made significant economic progress, with help from the UN, the EU, and the United States as well as decentralization and power sharing between Macedonians and Albanians. Greece's refusal to accept Macedonia's name, however, has stalled entry into NATO, slowed progress toward the EU, and aggravated ethnic tensions. A now agreed solution to the "name" issue would be a major gain for Macedonia and the region, if implemented in both countries. The door will then open for the "Republic of North Macedonia" to enter NATO and begin EU accession talks.
\end{abstract}

Keywords Conflict prevention - "Name" issue • Ohrid Framework Agreement - "Northern Macedonia"

Today's Macedonia owes its distinct and separate existence as a political entity to Socialist Yugoslavia. During the Yugoslav monarchy between the world wars, what is now Macedonia was initially the banovina (province) of Southern Serbia, which became Vardar Banovina in 1929. It was only after World War II that the Yugoslav Republic of Macedonia came into existence. In Tito's way of thinking, Macedonian identity-based

(C) The Author(s) 2019

D. Serwer, From War to Peace in the Balkans, the Middle East and Ukraine, Palgrave Critical Studies in Post-Conflict Recovery, https://doi.org/10.1007/978-3-030-02173-3_4 
on language, history, and religion-was useful because it fended off both Bulgarian territorial and Serbian identity claims. The modern Macedonians are, however, Slavs, not Greeks. Their language is Slavic and related to Bulgarian, but distinct from Serbo-Croatian (now termed Serbian, Croatian, Montenegrin, or Bosnian, depending on whom you are talking to). Whatever antecedents existed for Macedonian identity, it is hard to picture how a Macedonian state would have emerged when it did without a big boost from Socialist Yugoslavia.

But Macedonia has never been all ethnically Macedonian. There is a reason the French and Italians call a mixed-fruit salad a macédoine/macedonia. The numerically largest minority is Albanian, about one-quarter of the population. Mother Teresa is the best-known Albanian from what is today Macedonia (born in Skopje in 1910). Ten percent are Turks, Roma, Serbs, Bosniaks, and other Yugoslavs as well as Vlachs and Bulgarians. The country is thoroughly mixed ethnically, even if the Albanian population is concentrated in the northwest and in the capital, Skopje (Shkup in Albanian). Some Albanians in Macedonia would have preferred to be part of a majority in Kosovo or Albania. Some of its Serbs would have preferred to be part of the majority in Serbia. Its Bulgarians - as well as Greek neighbors and others in the Balkanshave often viewed Macedonia and its language as nothing more than an offshoot of Bulgaria and Bulgarian. It is not easy to be an ethnically mixed country in the Balkans, especially when your northern neighbors (majority-Albanian Kosovo and majority-Slavic Serbia) are fighting and your two largest populations speak mutually incomprehensible mother tongues.

So the dissolution of Yugoslavia certainly put Macedonia at risk. The centrifugal forces were strong. When Slovenia and Croatia left the Yugoslav Federation in 1991, Macedonia had to follow or risk being left in a Serb-dominated Federation. It held a referendum in September 1991 that was approved by $99 \%$ of the $72 \%$ of registered voters who went to the polls. Most Albanians and Serbs boycotted. Albanians disliked the idea of independence because it would separate them from their compatriots in Kosovo. Pristina and its university were historical, cultural, and intellectual centers of Albanian nationalism. Albanians in Macedonia had easy communication with Albanians in Kosovo during the Socialist period, when the boundary was invisible and porous, like the boundary between Virginia and Maryland (or today France and Germany). Independence inserted an international 
border between branches of Albanian families. Serbs likewise disliked Macedonian independence because it would separate them from Serbia and weaken whatever Serb-dominated state emerged from Socialist Yugoslavia.

Why did war not follow? The other ingredients were diluted, and the international community was far more proactive. ${ }^{1}$ Serbian nationalism had nowhere near the same significance in Macedonia as it had in Bosnia. Serbs officially represented only $2 \%$ of the population in the last Socialist census, and Macedonian identity was strongly felt by more than $65 \%$ of the population. ${ }^{2}$ Milošević was preoccupied with Croatia and Bosnia, both of which had larger percentages of Serbs. He had already abandoned the effort to hold on to Slovenia, where few Serbs lived. He withdrew the Yugoslav National Army from Macedonia without shots fired in February 1992. Leaving Macedonia with a weak army based on its Yugoslav territorial reserve forces (a home guard), it represented no threat and would be easy pickings later, if Milošević so desired. Neither his political ambitions nor Serbian nationalism were immediately at stake.

Macedonian President Kiro Gligorov in November 1992 requested UN observers to ensure his country's territorial integrity. His immediate concern was the possible impact of fighting elsewhere in former Yugoslavia, especially an influx of refugees from Kosovo that might trigger Albanian and Serbian intervention, as well as Turkish and Greek responses. Macedonia was not yet a UN member. Gligorov, acutely aware of his country's need for international recognition, wanted to protect its sovereignty and independence, increase its diplomatic profile, and prevent war from spreading into its territory. ${ }^{3}$ An international peacekeeping force would serve all these purposes, even if the conventional military threat proved minimal.

Lucky Macedonia not only got the UN's first explicitly preventive deployment, UNPREDEP, but also benefited from Nordic and eventually U.S. troops, who were sent as a token by President Bill Clinton because Macedonia was relatively safe for peacekeepers compared to Croatia and Bosnia, where European observers were already under fire. UNPREDEP stayed in Macedonia until early 1999, working hard but somewhat surreptitiously to solidify the country internally as well as to observe and report on external threats, including those arising from the breakdown of law and order in Albania during 1996 and 1997 and in Kosovo in 1998 and 1999. The UN mission was withdrawn due to a Chinese veto in the UN Security Council after Macedonia, in an ill-fated 
move meant to attract investment, recognized and established diplomatic relations with Taiwan, shortly before the long-feared outflow of Albanian refugees from Kosovo actually began.

While Gligorov's worst fears did not materialize, one neighbor did peacefully but energetically contest one aspect of Macedonian statehood, the country's name, at independence and for more than twenty-five years thereafter. Greece claimed the exclusive right to the label "Macedonia" for one of its provinces. Athens also asserted that Skopje's use of it entailed a claim on Greek territory. The authorities in Skopje have not asserted such a claim, and the third article in the country's constitution, adopted to satisfy Athens, precludes one: "The Republic of Macedonia has no territorial pretensions towards any neighboring state." Macedonia also changed its flag and deleted numerical estimates of the Macedonian minority in Greece from its foreign ministry website to please Athens, all to no avail. ${ }^{5}$ Macedonia in any event is far too weak militarily to represent a threat to Greece, which Skopje would prefer to have as a NATO ally rather than an adversary.

When asked for evidence of Macedonian irredentism, Greeks routinely whip out a photograph showing a map allegedly displayed in Macedonian schoolrooms that depicts the Macedonian flag blanketing not only Macedonia's sovereign territory but also Greece's northern provinces. Macedonians claim this is a depiction of the extent of ethnic Macedonian presence, not a claim to territory. But that is little comfort to Greeks, who are loath to admit the existence of minorities within their own population and claim that "Macedonia," a name associated with more than twelve hundred places in the United States, belongs exclusively to Greece and its supposedly pure Hellenic tradition, traced back without interruption to the ancients.

Skopje was nevertheless admitted to the United Nations as The Former Yugoslav Republic of Macedonia (The FYROM: alphabetized in the General Assembly under "T") in 1993, a temporary expedient that Greece agreed in 1995 could be used in other international bodies as well. ${ }^{6}$ The United Nations, mostly in the person of American lawyer Matthew Nimitz, tried for the next twenty-five years to resolve the "name" issue. As special representative of the UN secretary-general, Nimitz shuttled between Athens and Skopje, occasionally convening the parties for a discussion of proposals. The Greeks wanted a new constitutional name without "Macedonia" that would have to be used for all purposes (erga omnes is the Latin term of art). The Macedonians wanted 
one that could be readily shortened to "Macedonia," which they intend to keep using. The dispute proved intractable, because like so many other Balkan issues it pitted one ethnic identity and nationalism, Greek, against another, Macedonian.

Greek preoccupation with the name issue is rooted in Athens's own attitude toward minorities within Greece, as it denies they exist, and related claims about Greek identity. Coached by nationalist politicians, many Greeks want to believe that they are descended directly from the ancient Greeks and have exclusive rights to that distinction. Anyone who knows the history of barbarian and Slavic invasions as well as the consequent mixing of gene pools should have doubts about that claim. The population of Athens was fewer than 10,000 in $1800 .^{7}$ It had been closer to 250,000 in the fifth century $\mathrm{BC}$ and is now more than 650,000 . What likelihood is there that today's Greek population is all descended from the ancient Greeks? Greek nationalism, and the claim to inheritance of ancient genes and culture, is not continuous but-like Serbian and Albanian nationalism - a product of the nineteenth century, specifically the romantic awakening associated with the British poet Lord Byron, who died in Greece after fighting for its independence from the Ottomans.

Whatever its origins, the consequences of the name issue were pernicious. Greece's former Prime Minister Antonis Samaras went so far as to say that he wanted to see the dissolution of Macedonia and the formation of a Greater Albania, rather than accept a solution that included "Macedonia." 8 Some Macedonians do claim to be descended from the ancient Greeks, and their past leadership, in particular Prime Minister Nikola Gruevski, touted that connection, but most realize that neither genetic nor cultural lineage is likely, especially as their language is Slavic. ${ }^{9}$ President Gligorov in the 1990s used to explicitly deny any connection to the ancient Macedonians.

While the name issue remained an irritant for more than twenty-five years, the bigger immediate threat to the Macedonian state at independence did not come from Greece, which became an important investor and trading partner despite its hostility to the name "Macedonia." The threat came initially from inside the country. At independence, Albanians were $21.7 \%$ of the population. Their members of parliament abstained from voting on the new constitution, which treated the new state as belonging to "the Macedonian people." Only gradually did Albanians in Macedonia begin to participate actively in governing the country. Today an unwritten 
but so far inviolate power-sharing rule requires that one of their larger vote-getting parties join the government and be given substantial portfolios. The Albanians do not object to calling the country "Macedonia," but they want to see the name issue resolved to enable NATO membership, which they view as a guarantee of the democratic future of the country and its willingness to protect its non-Macedonian citizens.

The "Albanian question"- that is, whether the Albanians will live in many countries or in just one Greater Albania-has arisen repeatedly in the more than twenty-five years of Macedonia's independence. It became acute in 1999. Macedonia received about 350,000 Kosovo Albanian refugees chased out by Serb forces during March, April, and May of that year, well over $10 \%$ of the Macedonia's population. The influx significantly increased the number of Macedonia's Albanian inhabitants and threatened to destabilize a still weak state. Nevertheless, Gligorov's nightmare scenario of Albanian, Serbian, Greek, and Bulgarian involvement, often repeated by Richard Holbrooke, never materialized, in part because the warnings mobilized American and European diplomats to effective prevention. The peacekeepers were gone, but Macedonia managed the crisis effectively, with a great deal of international assistance. ${ }^{10}$

It was not the Albanian refugee influx during the Kosovo War that put Macedonia at serious risk. In June 1999 the Kosovar refugees returned rapidly as soon as Serbian forces withdrew. They left behind a still weak state, one that had not yet done much to convince its Albanian population that it would be treated well enough to offset the losses from separation from Albanians in Kosovo.

The full story of the Albanian rebellion in Macedonia in 2001 has not been told. ${ }^{11}$ The insurgency was fed from southern Serbia and Kosovo, in part by Albanians who had not done well politically in Kosovo's first postwar elections and were seeking other outlets. But there were real grievances inside Macedonia as well. Though Albanian political parties had begun to participate in Macedonian governments, Albanians still felt that they were being treated like second-class citizens. They sought official recognition of their language, which is a vital dimension of Albanian identity, and of the multilingual University of Tetovo, established in 1994, as well as permission to use the ethnic Albanian flag (which also doubles as the flag of Albania). They sought equality in the Macedonian administration and army. They wanted decentralization that would allow municipalities, some of which had Albanian majorities, more self-governance. 
The Albanians in Macedonia did not, however, seek to destroy the Macedonian state or open the door to union with Kosovo or Albania. Doing so would have put at risk Kosovo's still unfulfilled ambitions for independence. It would also have meant a thoroughly unsatisfactory territorial outcome. Macedonian Prime Minister Ljubčo Georgievski was open to partition of his country and even had the Macedonian Academy write an imitation of the Serbian Academy memorandum that had propounded nationalist goals. ${ }^{12}$ But he was unwilling to give up an inch of Skopje, which held the largest concentration of Albanians in the country. Nor did most Albanians in Macedonia want to open a Pandora's box, precipitating a series of partitions in Kosovo and Bosnia and destabilizing much of the Balkans. The 2001 Albanian rebellion was a violent one, but its militants accepted the territorial status quo and sought expanded Albanian political participation and rights within the existing state structure.

The seven months or so of conflict in 2001 did not end with a much-violated NATO-negotiated cease-fire but rather with signing of the Ohrid Framework Agreement, which provided Albanians in Macedonia with the promise of a stronger role in state institutions, more use of their language, and serious devolution of power to the municipal level. ${ }^{13}$ The basic ideas in the agreement had been put forward months earlier by Robert Frowick, the American head of the Organization for Security and Cooperation in Europe mission in Macedonia. European and American negotiators collaborated in mediating the negotiations and in developing the formal agreement, signed in August 2001. The National Liberation Army (NLA), which had conducted the rebellion, agreed to demilitarize, disarm, and reintegrate. It reemerged under its surprisingly mild-mannered commander, Ali Ahmeti, as the Democratic Union for Integration, which has outpolled its Albanian rivals while participating in Macedonian governments since 2002.

This is an instance of relatively early international engagement, mainly of a political sort but with NATO military power looming in the distance. The Macedonian government and the NLA were both ready to end the fighting, as neither had much capacity to escalate further without causing the Europeans and Americans to respond in ways that would hurt their respective causes. The Ohrid Agreement was a mutually enticing opportunity at a moment of mutually hurting stalemate, as it preserved the Macedonian state while guaranteeing Albanians a strong role within it. Macedonia might well have exploded in 2001 under 
pressure from Albanian nationalism, with catastrophic consequences for the Balkans and beyond. Prevention and early diplomatic intervention worked once again, because the ethnic nationalism was relatively attenuated and not associated with a clearly defined territory, military capabilities were limited, and political ambitions were restrained. Without Milošević's and Serbia's involvement, the fighting was blessedly brief and contained in the north, with combat deaths well below the 1000 victims that usually qualify as a war.

The history of Macedonia since then resembles Macedonia's folk dance, the oro: three steps forward, two steps back. It includes progress followed by deterioration on both the domestic and the international fronts. The progress on the domestic front is of two sorts: implementation of the Ohrid Agreement and improvement in the country's economic prospects.

The record on the Ohrid Agreement is modestly positive on decentralization, Albanian representation in state institutions, parliamentary safeguards, university education, language, and ethnic symbols. ${ }^{14}$ Ethnic Macedonians think Albanians should be satisfied, but they are not. ${ }^{15}$ As the American embassy put it: Ohrid "is still an effective tool to reduce the risk of another civil conflict, even though implementation has been a 'mixed bag." "16

The Albanians would like official use of their language by the Skopje government throughout the entire country as well as more fiscal decentralization to the municipal level than provided for in the original agreement. Some Macedonians resist, fearing a weakened "binational" state. A law regulating language use passed the parliament twice by early 2018, but President Gjorge Ivanov refused to sign it. The lack of taxation authority at the local level limits resources and local autonomy (and likely also patronage and corruption). Issues of this sort exist throughout much of Europe and in the United States. It might even be said that they are perpetual. Though subsidiarity (handling of issues at the lowest effective level) is by now a well-established principle in Europe, it is implemented in widely varying ways throughout the EU. ${ }^{17}$ The variations in municipal and other local government structures and powers are even greater in the United States.

Many of the other remaining issues concern the degree to which legislation has been implemented, in the spirit as well as the letter of the law. Years more will be required in Macedonia, even if things are moving generally in the right direction. Any faster pace might risk a backlash 
among Macedonians, some of whom treat every Albanian advance as their loss. In 2011, at the tenth-anniversary celebration of the Ohrid Agreement, the only major Macedonian politician to appear was the young foreign minister, Nikola Poposki. He made it clear he thought the Ohrid Agreement had saved his country, but precious few of his Macedonian colleagues would say it out loud. The agreement has not transformed relations between Macedonians and Albanians, even if it has relieved the most acute grievances felt on the Albanian side. Prevention has allowed a good deal of practical cooperation between Macedonians and Albanians, but it has not done a lot to break down their tradition of living separate, parallel lives. ${ }^{18}$

The other sense in which Macedonia has progressed is economic. During the first decade after independence, the sclerotic state-dominated economy had been held back by Greek hostility, painful privatizations, and the wars both farther north and in Macedonia itself. Macedonians used to complain bitterly about the small Albanian family-owned companies that paid few taxes and ignored the many regulations left over from the country's Socialist past. Many Macedonians in the 1990s were committed to large, non-competitive, state-owned enterprises left over from Socialist Yugoslavia. Few of those have survived.

There was virtue in the Albanian example. Skopje eventually began to encourage entrepreneurial success. Made an EU candidate country in 2005 , it lowered tax rates and streamlined regulations. The Macedonian economy is now rated the freest in the region. ${ }^{19}$ The government and citizens have also discovered that they can borrow, leading to large increases in public and private debt. The results have been dramatic. The economy stagnated for the decade after independence. Since 2001, GDP has tripled, despite near-recession in 2009 and 2010 due to the European recession, as well as declines in 2012 and 2015. That is a substantial peace dividend, even if it has not been shared equitably across the society.

There is one important but largely invisible international achievement in recent years for Macedonia: agreement on and demarcation of its border with Kosovo, which threatened to become a source of contention. The Kosovars were initially reluctant to demarcate a border that had been agreed upon not with Pristina but rather with Belgrade, before Kosovo's independence. With assistance from the Organization for Security and Cooperation in Europe, the job nevertheless got done. ${ }^{20}$ This vastly improved Skopje's relationship with Pristina. You can look 
long and hard for two countries that have good relations if the common border is under dispute (witness Pakistan/Afghanistan, for example, not to mention Israel/Palestine, China and its South and East China Sea neighbors). With the border issue on its way to being settled, Macedonia became a friendly neighbor, one that moved quickly to recognize Kosovo as a sovereign state when it declared independence.

The steps backward in Macedonia have often been more apparent than the less dramatic, but important, steps forward. In May 2015 a group of armed Albanians (some in battle dress uniforms) were killed near the Kosovo border by the Macedonian police, who also suffered significant losses. The origins and objectives of the alleged insurgents, at least some of whom appeared to have come from Kosovo, are still not clear. Many Albanians in Macedonia condemned the incursion. Some believe the incident may have been staged by the Macedonian government, or that it turned a blind eye and then intervened against the Albanians for political reasons. ${ }^{21}$ Whatever the truth of these allegations, the echo of the 2001 insurgency was all too perceptible. The "Albanian question" is not asked as loudly as the Serbian one, but it lurks in the background in Macedonia and Kosovo.

This incident occurred in the midst of a massive wiretapping scandal in Macedonia, the protagonists of which were rival Macedonian political leaders. Opposition leader Zoran Zaev had for months been releasing tapes and publishing transcripts of telephone conversations among officials of Prime Minister Gruevski's government, some involving the prime minister himself. ${ }^{22}$ The content and language were more than disturbing. In one conversation, the then head of the Security and Counter Intelligence Service, a cousin of the prime minister, laughingly talked about having a political opponent raped in prison. Another tape suggested that Gruevski, his interior minister, and other top officials plotted to cover up official responsibility for the death of a twenty-two-year-old beaten by police during Gruevski's 2011 post-election celebrations. ${ }^{23}$ The tapes pointed to official involvement in massive violations of human rights, voter fraud, extortion, corruption, fraud, interference in judicial matters, abuse of power, and cover-ups of other malfeasance. Gruevski alleged that the opposition collaborated with a foreign security service to get the taping done, but an EU group of experts determined that Macedonia's own security service did the illegal taping. ${ }^{24}$

The popular reaction was strong, but the electoral consequences were ambiguous. Massive demonstrations that included both Albanians 
and Macedonians advocated Gruevski's resignation, which occurred in January 2016 in accordance with an EU-brokered and U.S.-supported Przino Agreement providing also for early elections, once the voter rolls were repaired and verified. ${ }^{25}$ The elections took place in December 2016, with ambiguous results. Gruevski's party won the most seats in parliament, by two, but both it and its Albanian coalition partner lost seats relative to the previous election. Events and an international push dictated the outcome. Gruevski's supporters were implicated in a bloody attack on a newly elected Albanian Speaker in the parliament chamber in April 2017. That was the last straw for Washington and Brussels. A big diplomatic push from the Europeans and Americans, disgusted with Gruevski's behavior, brought Zaev to power the next month, with support from the Albanian party that had governed with Gruevski.

The Przino Agreement also created a new Special Public Prosecutor. She and her team of prosecutors have exclusive authority to open cases about the crimes exposed in the wiretapping scandal. She faces enormous obstacles, including institutional stonewalling and witness intimidation. A protected witness was found dead in his apartment, shot in the chest. President Ivanov halted investigations of fifty-six officials and their close associates, granting them preemptive pardons in April 2016. Under both domestic and international pressure, he rescinded the amnesties a month later. By mid-2017 the Special Prosecutor had indicted more than ninety people, including former Prime Minister Gruevski. He has been convicted, but so far on relatively minor charges. He faces more serious ones. Anything less than successful high-level prosecutions would contribute to an already entrenched culture of impunity in Macedonia and cast doubt on the potential of the EU and the United States to get Macedonia to deal effectively with corruption and democratic deterioration. Failure of the Special Prosecutor would no doubt also lead to disruptive and violent protests with a highly uncertain and potentially destabilizing outcome.

Once in power, Zaev still faced the name issue. Negotiations were stalled, as Gruevski saw no way of getting a better deal than the status quo: everyone except the Greeks was calling the country "Macedonia" or "Republic of Macedonia." The FYROM was already a member of Partnership for Peace, the NATO anteroom, and had met NATO's military criteria for membership. It was at one time the fourth-highest troop contributor per capita to NATO's forces in Afghanistan. Its army fought under U.S. command there and protected NATO headquarters in Kabul. 
The Vermont National Guard integrated Macedonian troops with their own fighting force in Afghanistan. The American commander said he relied on them as he would on American troops. ${ }^{26}$ Gruevski was getting many of the benefits of NATO membership without having to meet its political criteria, which include stable democratic governance, good relations with neighbors, and commitment to the rule of law and human rights. He was far less interested in meeting those requirements. He suffered from what has come to be known as the "Sanader effect," named for the prime minister of Croatia who turned his country definitively toward the EU but was arrested and convicted of corruption charges by its newly independent judiciary. Gruevski had no intention of suffering the same fate.

Greece, whose contributions to NATO in Afghanistan and elsewhere were not greater than Macedonia's, had shown no sign of easing its veto on NATO membership, which it had exercised informally since 2008 . Athens had little incentive to do otherwise, as the veto gave it leverage on the name issue. But the impasse aggravated ethnic tension between Macedonia's strongly pro-NATO Albanians and its majority-Macedonian population, which values the country's name more and harbors nationalist passions. It proved impossible to convince the Americans or the Europeans to pressure cash-strapped Greece to resolve the name issue, or at least to allow "The FYROM" the NATO membership it was permitted under the Interim Accord, despite a 15-1 International Court of Justice (ICJ) decision in 2011 favoring that solution. ${ }^{27}$ The court also denied Greece's counterclaim that Macedonia had itself violated anti-incitement provisions of the agreement. While Greeks claim that the court failed to adopt any remedies, the decision was a binding one that the ICJ, which relies on sovereign states to implement its decisions, expected Athens to implement without further ado. Greece's failure to do so cast a shadow on its reputation, but without any detectable impact on its position in the dispute.

While the ICJ decision held that the Macedonian government had not legally violated the Interim Accord, it still had its share of moral responsibility. Elected as an economic reformer but blocked from negotiations on EU accession, Gruevski had played to his ethnic nationalist constituency by emphasizing connections to ancient Macedonia that were even more far-fetched than those of his principal adversary, former Greek Prime Minister Samaras. Like the ethnic nationalists in Bosnia, Gruevski and Samaras each gained from antagonism toward the other. 
The arguably corrupt and inordinately expensive reconstruction of central Skopje (2010-14) that Gruevski engineered to echo imagined ancient Macedonian greatness is no more than kitsch to most of us, but that does not make it less offensive to someone like Samaras. Those of us who live in Washington, DC, find it hard to complain about faux statues of the ancients, as our capital city was explicitly designed as the "New Rome" and sports many American heroes draped in togas, not to mention a main reading room at the Library of Congress that would make Augustus Caesar blush. No one in Italy has objected-the Italian government has even contributed a few faux Romans to Washington's menagerie. But in the Balkans, ethnic identity is a more sensitive issue. Gruevski's pretensions unquestionably escalated the name dispute.

Samaras fell from power in 2015 and Gruevski in 2017. The leadership changes were decisive. Their less nationalist successors, Alexis Tsipras and Zaev, seized the opportunity to begin serious efforts to resolve the name issue, relying on their capable foreign ministers, Nikos Kotzias and Nikola Dimitrov. Skopje took some unilateral confidence-building steps: it renamed its airport "Skopje International" and a main highway "Friendship," both of which Gruevski had called "Alexander the Great." Athens and Skopje also agreed to an elaborate set of confidence-building measures intended to improve "connectivity" and trust between the two countries in fields such as education, health, culture, justice, and energy. By mid-2018 the two countries had reached agreement, signed at Lake Prespa on their common border, on "Republic of North Macedonia" as the official name (erga omnes), though private citizens will continue to call themselves and their language Macedonian. ${ }^{28}$ Skopje also acknowledges that Macedonian is a Slavic language without connection to ancient Greece and accepts that it will not interfere in Greece in favor of the ethnic Macedonian minority there. Textbooks and other educational materials are to be reviewed and changed as needed. Both countries forswear any irredentist claims on, or subversive acts toward, the other. Unlike the Dayton Accords, the Prespa Agreement aims to remove drivers of conflict. ${ }^{29}$

NATO responded unequivocally with an invitation, issued at the July 2018 NATO Summit in Brussels, for the Republic of North Macedonia to join the Alliance. The EU was more hesitant, as it faces resistance from several members who want to see reforms within the EU before further enlargement. While that disappointed some, the EU nevertheless has pledged to start accession negotiations with North Macedonia by the 
end of 2019. Macedonia would benefit enormously from ending frictions that for too long both Macedonian and Greek nationalist leaders have found useful for domestic political purposes, even if doing so is dangerous and destabilizing. But the agreement on the new name still faces serious hurdles. A September 2018 advisory referendum in Macedonia approved the agreement but failed to turn out $50 \%$ of registered voters. The agreement was nevertheless approved by a two-thirds margin in the Macedonian parliament, which still however needs to adopt constitutional amendments. The Greek parliament will also have to approve the agreement. The Greek parliament will present a more serious hurdle, as Tsipras' government has a thin majority. "North Macedonia" has elicited opposition demonstrations in both capitals. The Greeks object to "Macedonia." The Macedonians object to "North." Moscow will do its best to amplify nationalist resistance on both sides, as Russia seeks to block any new NATO memberships. ${ }^{30}$

Like other Balkan countries, Macedonia behaves like a bicycle. Without forward motion, it tends to fall over. While the counterfactual is subject to debate, Macedonia's struggles over the past few years would likely not have occurred had it already been a NATO member or a candidate for the EU. Skopje escaped the ravages of war in the Milošević era due in part to deployment of UN peacekeepers from Europe and the United States, stepped back from the brink in 2001 with help from the EU and the United States, recovered sufficiently to enjoy the benefits for fifteen relatively prosperous years, and stepped back from the brink again in 2018, when new leadership in both Skopje and Athens reached a negotiated agreement with assistance from the UN and a lot of encouragement from the EU and the United States. Failure to gain NATO membership and to start accession negotiations with the European Union had blunted the forward momentum of the country's economic reforms and left it vulnerable, but it now has a new opportunity to reach its two most important national goals.

\section{Notes}

1. The story of Macedonia's first decade after independence and the international support it got is told in Henryk J. Sokalski, An Ounce of Prevention: Macedonia and the UN Experience in Preventive Diplomacy (Washington, DC: United States Institute of Peace Press, 2003); Abiodun Williams, Preventing War: The United Nations and Macedonia (Lanham, MD: Rowman \& Littlefield, 2000). 
2. Thomas S. Szayna and Michele Zanini, "The Yugoslav Retrospective Case, Annex: Demographic Characteristics of Yugoslavia in the Late 1980s," in Identifying Potential Ethnic Conflicts: Application of a Process Model, ed. Thomas S. Szayna (Santa Monica, CA: RAND, 1997), 130.

3. Matjaž Klemenčič, "The International Community and the FRY/ Belligerents, 1989-1997," in Confronting the Yugoslav Controversies: A Scholars' Initiative, ed. Charles W. Ingrao and Thomas Allan Emmert (West Lafayette, IN: Purdue University Press, 2009), 169.

4. Amendment I, Constitution of the Republic of Macedonia, http://www. wipo.int/edocs/lexdocs/laws/en/mk/mk014en.pdf.

5. "Macedonia Erases 'Irredentist' Claims as Commission Tables Report," EurActiv.com, last modified April 18, 2013, https://www.euractiv.com/ section/enlargement/news/macedonia-erases-irredentist-claims-as-commission-tables-report/; Haralambos Kondonis, "Bilateral Relations between Greece and the Former Yugoslav Republic of Macedonia," in Athens-Skoplje: An Uneasy Symbiosis, 1995-2002, ed. Evangelos Kofos and Vlasis Vlasidis (Athens: Papazisis, 2003), 57.

6. United Nations Peacemaker, "Interim Accord between Greece and the Former Yugoslav Republic of Macedonia," September 13, 1995, https://peacemaker.un.org/greecefyrom-interimaccord95.

7. John Cam Hobhouse, A Journey through Albania and Other Provinces of Turkey in Europe and Asia, to Constantinople, during the Years 1809 and 1810 (London: Printed for James Cawthorn, 1813).

8. TV Sonce, "Samaras-English," YouTube Video, 4:43, January 27, 2009, https://www.youtube.com/watch? $=$ QnCrRXJAJeU.

9. There is little genetic evidence of connection to the ancient Greeks, or variation among any of the Balkans ethnicities, except possibly the Vlachs (aka Aromuns). See E. Bosch et al., "Paternal and Maternal Lineages in the Balkans Show a Homogeneous Landscape over Linguistic Barriers, Except for the Isolated Aromuns," Annals of Human Genetics 70, no. 4 (July 2006): 459-87, http://www.carswell.com.au/wp-content/documents/homogenous-balkan-analysis.pdf.

10. Doneo Donev, Silvana Onceva, and Ilija Gligorov, "Refugee Crisis in Macedonia during the Kosovo Conflict in 1999," Croatian Medical Journal 43, no. 2 (2002): 184-89, http://neuron.mefst.hr/docs/CMJ/ issues $/ 2002 / 43 / 2 / 11885045$.pdf.

11. Veton Surroi, The Book of Butterflies (Pristina: Koha, 2013). Surroi tells the story of the political negotiations in which he played an important role, but he repeatedly claims he did not know who constituted the National Liberation Army. Ali Ahmeti, its leader and now a leading politician in Macedonia, told me in April 2018 that the rebellion was plotted from Switzerland, with capabilities built up as early as the 1990s. 
12. Nevena Dimova, "Macedonian and Albanian Intellectuals and the National Idea(s) in Socialist Macedonia," in Avatars of Intellectuals under Communism, ed. Corina Palasan and Cristian Vasile, History of Communism in Europe 2 (2011): 244-45.

13. Peace Accords Matrix, "Ohrid Agreement," Kroc Institute for International Peace Studies University of Notre Dame, August 13, 2001, https://peaceaccords.nd.edu/accord/ohrid-agreement.

14. European Stability Initiative, "The Ohrid Agreement and Its Implementation," https://www.esiweb.org/index.php?lang=en\&id=563.

15. Demush Bajrami and Arburim Iseni, "The Challenge of (Non) Implementation of the Ohrid Framework Agreement in the Republic of Macedonia," European Scientific Journal 10, no. 10 (April 2014): 203-18.

16. "Cablegate: Macedonia: The Ohrid Framework Agreement," Scoop Wikileaks, January 6, 2010, https://balkanleaks.eu/242.

17. EUR-Lex, "The Principle of Subsidiarity, Glossary of Summaries," https://eur-lex.europa.eu/summary/glossary/subsidiarity.html.

18. Florian Bieber et al., Power Sharing and the Implementation of the Ohrid Framework Agreement (Skopje: Friedrich Ebert Shtiftung, Office Macedonia, 2008), http://library.fes.de/pdf-files/bueros/skopje/06357.pdf.

19. 2018 Index of Economic Freedom the Heritage Foundation, "Macedonia" (2018), https://www.heritage.org/international-economies/commentary/ 2018-index-economic-freedom.

20. Unrepresented Nations and Peoples Organization, "Kosova: Border Demarcation Begins," August 24, 2012, http://www.unpo.org/ article/14753.

21. Benjamin Arifi, "Smoke and Mirrors: A Macedonian Spy Mystery," Balkan Insight, May 9, 2018, http://www.balkaninsight.com/en/ article/smoke-and-mirrors-a-macedonian-spy-mystery-05-08-2018.

22. Radio Free Europe/Radio Liberty, “The Explainer: Roots of Macedonia's Political Crisis Run Deep," https://www.rferl.org/a/explainer-crisis-in-macedonia-leads-to-violent-protests/27675969.html.

23. "Macedonia Officials Attempted Murder Coverup," Balkan Insight, May 15, 2015, http://www.balkaninsight.com/en/article/macedoniaofficials-attempted-murder-cover-up-opposition-claims.

24. The Former Yugoslav Republic of Macedonia: Recommendations of the Senior Experts' Group on Systemic Rule of Law Issues Relating to the Communications Interception Revealed in Spring 2015, Brussels June 8, 2015, https://ec.europa.eu/neighbourhood-enlargement/sites/near/ files/news_corner/news/news-files/20150619_recommendations_of_ the_senior_experts_group.pdf. 
25. The Przino Agreement is at https://ec.europa.eu/neighbourhood-enlargement/sites/near/files/news_corner/news/news-files/20150619_ agreement.pdf and "Statement by Commissioner Hahn and MEPs Vajgl, Howitt and Kukan: Agreement in Skopje to Overcome Political Crisis," European Union, July 2015, http://europa.eu/rapid/ press-release_STATEMENT-15-5372_en.htm.

26. Daniel Serwer, "The Western Balkans and the 2012 NATO Summit," Hearing before the Commission on Security and Cooperation in Europe: US Helsinki Commission, January 18, 2012, https://evergreen.lib. in.us/eg/opac/record/19788997.

27. International Court of Justice, "Application of the Interim Accord of 13 September 1995 (the Former Yugoslav Republic of Macedonia v. Greece)," http://www.icj-cij.org/en/case/142.

28. Final Agreement for the Settlement of the Differences as Described in the United Nations Security Council Resolutions 817 (1993) and 845 (1993), the Termination of the Interim Accord of 1995, and the Establishment of a Strategic Partnership between the Parties, http:// www.pappaspost.com/wp-content/uploads/2018/06/Athens-SkopjeEnglish.pdf.

29. Edward P. Joseph and Ognen Vangelov, "Breakthrough in the Balkans: Macedonia's New Name," Survival 60, no. 4 (2018): 37-44, https:// doi.org/10.1080/00396338.2018.1495426.

30. Saska Cvetkovska, "Russian Businessman behind Unrest in Macedonia," Organized Crime and Corruption Reporting Project, July 16, 2018, https://www.occrp.org/en/28-ccwatch/cc-watch-indepth/8329-russian-businessman-behind-unrest-in-macedonia. 
Open Access This chapter is distributed under the terms of the Creative Commons Attribution 4.0 International License (http://creativecommons.org/ licenses/by/4.0/), which permits use, duplication, adaptation, distribution and reproduction in any medium or format, as long as you give appropriate credit to the original author(s) and the source, a link is provided to the Creative Commons license and any changes made are indicated.

The images or other third party material in this chapter are included in the work's Creative Commons license, unless indicated otherwise in the credit line; if such material is not included in the work's Creative Commons license and the respective action is not permitted by statutory regulation, users will need to obtain permission from the license holder to duplicate, adapt or reproduce the material.

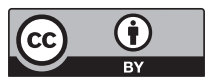

